\title{
Taxonomy of rigid rod-shaped viruses transmitted by fungi
}

\author{
Jianping Chen *, TMA Wilson \\ Scottish Crop Research Institute, Invergowrie, Dundee DD2 5DA, UK
}

(Received 20 May 1995; accepted 4 July 1995)

\begin{abstract}
Summary - Of 12 plant viruses with rigid rod-shaped particles transmitted by Plasmodiophoraceous fungi, 6 (soilborne wheat mosaic (SBWMV), oat golden stripe (OGSV), Indian peanut clump (IPCV), peanut clump (PCV), potato mop-top (PMTV) and sorghum chlorotic spot viruses (SCSV)) are definite members of the Furovirus genus. Six others (beet necrotic yellow vein (BNYVV), beet soil-borne (BSBV), broad bean necrosis (BBNV), rice stripe necrosis (RSNV), Hypochoeris mosaic (HMV) and Nicotiana velutina mosaic viruses (NVMV)) are possible members of the genus. The furoviruses infect cereal, potato and sugar beet crops grown in temperate or sub-tropical regions. The 2 beet viruses are transmitted by Polymyxa betae, PMTV by Spongospora subterranea, HMV and NVMV have unknown vectors, and the remaining 7 viruses are transmitted by $P$ graminis. Molecular analysis showed that SBWMV, BNYVV and PMTV differ in numbers of RNA species and genome organization, suggesting that they should be considered to represent 3 distinct subgenera of the Furovirus genus.
\end{abstract}

\section{taxonomy / transmission / fungi / epidemiology / genome organization}

Résumé - Taxonomie des virus en bâtonnets rigides transmis par champignons. Sur 12 virus à particules en bâtonnets rigides, transmis par des champignons du groupe des Plasmodiophoraceae, 6 virus [le virus de la mosaique du blé (SBWMV), le virus de la mosaique de l'avoine (OGSV), le virus indien du clump de l'arachide (IPCV), le virus du clump de l'arachide (PCV), le virus de la fasciation de la pomme de terre (PMTV), le virus des taches chlorotiques du sorgho (SCSV)] sont des membres bien établis. Six autres [le virus de la rhizomanie de la betterave (BNYVV), le virus de la betterave transmis par le sol (BSBV), le virus de la nécrose de la fève BBNV), le virus des rayures nécrosantes du riz (RSNV), le virus de la mosaïque de l'Hypochoeris (HMV) et le virus de la mosaíque du Nicotiana velutina (NVMV)] sont des membres possibles. Les furovirus infectent les céréales, la pomme de terre, et la betterave cultivées dans les régions tempérées ou sub-tropicales. Les 2 virus de betterave sont transmis par Polymyxa betae, PMTV par Spongospora subterranea, les vecteurs du HMV, du BNYVV et du PMTV diffèrent, et les 7 autres virus sont transmis par $\mathrm{P}$ graminis. L'analyse moléculaire a montré que SBWMV, BNYVV et PMTV diffèrent par le nombre de segments de RNA et par l'organisation de leurs génomes, ce qui suggère qu'ils devraient être considérés comme représentant 3 sous-genres distincts du genre furovirus.

\section{taxonomie / transmission / champignon / épidémiologie / organisation des génomes}




\section{INTRODUCTION}

About 12 plant viruses with rigid rod-shaped particles and divided positive-strand RNA genomes composed of 2 or more separately encapsidated components are known to be transmitted by Plasmodiophoraceous soil-inhabiting fungi (Polymyxa graminis, $P$ betae or Spongospora subterranea, table I). This genus of viruses was first proposed as the Furovirus genus (fungusborne rod-shaped virus group) by Shirako and Brakke in 1984 and approved by the International Committee on Virus Taxonomy and Nomenclature in 1987 (Brown, 1989). Some members of the genus had previously been classified in the Tobamovirus genus based on similar particle morphology, coat protein molecular weight and a weak serological relationship between tobacco mosaic virus (TMV) and potato mop-top virus (PMTV) or soil-borne wheat mosaic virus (SBWMV).

SBWMV is the type member of the Furovirus genus which also contains oat golden stripe virus (OGSV), Indian peanut clump virus (IPCV), peanut clump virus (PCV), potato mop-top virus (PMTV) and sorghum chlorotic spot virus (SCSV) as definitive members. Beet necrotic yellow vein virus (BNYVV), beet soil-borne virus (BSBV), broadbean necrosis virus (BBNV) and rice stripe necrosis virus (RSNV) are possible members. Although Hypochoeris mosaic virus (HMV) and Nicotiana velutina mosaic virus (NVMV) have no known vectors, they have properties which suggest that they too might be part of the Furovirus genus.

Furoviruses, particularly SBWMV, BNYVV and PMTV are of great agricultural and scientific

Table I. The natural occurrence of furoviruses.

\begin{tabular}{|c|c|c|c|c|c|}
\hline Crop type & Virus & Vector ${ }^{\mathrm{a}}$ & Main hosts & Symptom & $\begin{array}{l}\text { Geographical } \\
\text { distribution }\end{array}$ \\
\hline \multirow[t]{4}{*}{ Cereals } & OGSV & $\mathrm{Pg}$ & Avena sativa (oat) & Bright yellow leaf stripes & UK, France, USA \\
\hline & RSNV & $\mathrm{Pg}$ & Oryza sativa (rice) & Stunting chlorotic leaf stripes & Ivory Coast \\
\hline & SBWMV & $\mathrm{Pg}$ & $\begin{array}{l}\text { Secale cereale (rye) } \\
\text { Triticum aestivum (wheat) }\end{array}$ & Stunting mosaic & $\begin{array}{l}\text { USA, Italy, France } \\
\text { Japan, China, Brazil }\end{array}$ \\
\hline & SCSV & $?$ & Sorghum bicolor (sorghum) & Chlorosis & USA \\
\hline \multirow[t]{3}{*}{$\begin{array}{l}\text { Root and } \\
\text { tubers }\end{array}$} & BNYVV & $\mathrm{Pb}$ & $\begin{array}{l}\text { Beta vulgaris (var) } \\
\text { B saccarifera (sugarbeet) } \\
\text { Spinacia oleracea (Swiss chard) }\end{array}$ & $\begin{array}{l}\text { Rhizomania, stunting } \\
\text { chlorosis, necrosis }\end{array}$ & $\begin{array}{l}\text { Europe, China } \\
\text { USA, FSU, Japan }\end{array}$ \\
\hline & BSBV & $\mathrm{Pb}$ & Beta vulgaris & Rhizomania & $\begin{array}{l}\text { Western and } \\
\text { Northern Europe, USA }\end{array}$ \\
\hline & PMTV & Ss & $\begin{array}{l}\text { Solanum tuberosum } \\
\text { (potato) }\end{array}$ & $\begin{array}{l}\text { Yellow leaf markings, } \\
\text { stunting, spraying }\end{array}$ & $\begin{array}{l}\text { South America, } \\
\text { Northern and Central } \\
\text { Europe, Japan }\end{array}$ \\
\hline \multirow[t]{2}{*}{ Legumes } & BBNV & $\mathrm{Pg} ?$ & Vicia faba (broad bean) & $\begin{array}{l}\text { Stunting, chlorosis } \\
\text { necrosis }\end{array}$ & Japan \\
\hline & $\begin{array}{l}\text { IPCV } \\
\text { PCV }\end{array}$ & $\mathrm{Pg}$ & $\begin{array}{l}\text { Arachis hypogaea (peanut) } \\
\text { Sorghum arundinaceum } \\
\text { S bicolor (sorghum) } \\
\text { Setaria italica }\end{array}$ & $\begin{array}{l}\text { Stunting, } \\
\text { reduced leaf size, } \\
\text { poor roots }\end{array}$ & $\begin{array}{l}\text { West Africa, } \\
\text { India }\end{array}$ \\
\hline \multirow[t]{2}{*}{ Weeds } & HMV & $?$ & $\begin{array}{l}\text { Hypochoeris radicata } \\
\text { Leontodon autumnale }\end{array}$ & Chlorosis & $\begin{array}{l}\text { Canada, Australia } \\
\text { UK }\end{array}$ \\
\hline & NVMV & $?$ & Nicotiana velutina & Bright yellowing & Australia \\
\hline
\end{tabular}

a Fungal abbreviations: $\mathrm{Pb}=$ Polymyxa betae Keskin, $\mathrm{Pg}=$ Polymyxa graminis Ledingham, $\mathrm{Ss}=$ Spongospora subterranea (Wallr) . Laberh. 
interest. They infect cereals, sugar beet and potato and occur worldwide in both sub-tropical and temperate regions. Therefore intensive studies have been carried out on them. Recent molecular studies on the structure and organization of the viral genomes indicate that both BNYVV and PMTV possess some features setting them apart from the type member, SBWMV, and should probably be put into separate subgenera (Jupin et al, 1991; Shirako and Wilson, 1993; Scott et al, 1994; Kashiwazaki et al, 1995).

\section{NATURAL TRANSMISSION}

Furoviruses are naturally transmitted by either $P$ graminis (SBWMV, OGSV, IPCV, PCV and RSNV), $P$ betae (BNYVV and BSBV), or Spongospora subterranea (PMTV) in a persistent manner or via in vivo acquisition (Campbell, 1993). Although no vectors have been identified for BBNV and SCSV, $P$ graminis is most likely. The life-cycle of each of the 3 fungal vectors consists of biflagellate zoospores, multinucleate plasmodia, zoosporangia and thick-walled resting spores in clusters or cystosori. The primary zoospores, produced by resting spore germination, swim to the host's root hairs or epidermal surfaces where they encyst, penetrate, and develop into zoosporangia. The zoosporangia release secondary zoospores which continue the infection cycle or form cystosori which can survive in soil for many years.

Although the evidence is not conclusive, the virus is probably always carried inside zoospores, and also persists inside the fungal resting spores. SBWMV can be acquired by virus-free vector from virus-infected roots, and then be transmitted to healthy plants by the viruliferous vector. Although observations of thin sections of infected roots in the electron microscope have failed to detect SBWMV within fungal plasmodia or zoospores, a similar virus-vector relationship has been identified using immunogold labelling-electron microscopy to localize barley mild mosaic bymovirus (BaMMV) and BNYVV particles within the plasmodia and zoospores of $P$ graminis and $P$ betae, respectively (Chen et al, 1991; Rysanek et al, 1992). Only a small proportion (1-2\%) of the zoospores appeared to carry virus, but once a zoospore is viruliferous, the number of virions it carries is very large, up to 3 000-7 000 particles (Chen et al, 1991). The number of virus particles increases with the development of zoosporangia and some zoospores also contain cylindrical inclusion bodies ( $\mathrm{J}$ Chen, unpublished results). The function of these bodies is not know conclusively, but since they are encoded by the virus genome in other viruses, it seems possible that the viral RNA had been translated and may even have been replicated in the vector.

\section{DISEASE EPIDEMIOLOGY}

Furoviruses occur naturally in temperate and sub-tropical regions, although some members have a restricted geographical distribution. Because they are retained in resting spores in soil for many years it is difficult to control the disease once a field becomes infested with viruliferous fungi.

In China, soil-borne cereal viruses became a serious agricultural problem in the 1970s when some susceptible cereal cultivars, such as Zhaosu 3, were grown continuously on a large scale. Once a susceptible cultivar whose seeds were contaminated with viruliferous soil, was introduced into a new area, and grown for 5-7 years, the incidence of disease increased to $100 \%$. The Ministry of Agriculture in China estimates that, within a decade, about $7 \times 10^{6}$ hectares of cereals on the east coast (one of the main cereal growing areas) have become heavily infected and the annual cereal yield loss is 400000 tons.

SBWMV can cause losses of up to $80 \%$, although values of $10-50 \%$ are more typical. Losses due to BNYVV in European sugar beet can amount to $30 \%$.

The factors which influence disease transmission are the same as those that affect development of the vectors. The most important of these are soil moisture and relative humidity, soil temperature and $\mathrm{pH}$. Since zoospores require moisture for release and motility, furovirus infections are most evident after extended damp weather or excessive irrigation. The optimal temperature for growth of the fungal vectors is $18^{\circ} \mathrm{C}$, resting spores do not germinate at $5^{\circ} \mathrm{C}$, and zoospores become immobile at $28^{\circ} \mathrm{C}$. Thus SBWMV, BNYVV and PMTV become problems when the soil temperatures are around $15-18^{\circ} \mathrm{C}$ and symptoms in infected plants are more conspicuous when the temperature is below $20^{\circ} \mathrm{C}$. By contrast, PCV and IPCV spread efficiently in soil at $28^{\circ} \mathrm{C}$ or more in West Africa and India. $\mathrm{pH}$ appears to act mainly through its effect on the fungal vectors. The $\mathrm{pH}$ of highly contaminated 
fields is usually neutral to slightly alkaline and decreasing the soil $\mathrm{pH}$ to $5.0-5.5$, by spreading sulphur can significantly reduce the disease incidence.

\section{DISEASE CONTROL}

At present, the conventional control measures include rotation of non-host crops, delayed crop sowing, increasing fertilizer application and use of resistant cultivars. Rotation of non-host crops only reduces the effective 'titre' of a field inoculum, but does not eliminate disease occurrence. Delayed crop sowing in autumn reduces the number of SBWMV-infected winter plants, presumably because a less prolonged period of damp and optimal temperature decreases the opportunity for fungus infection before winter dormancy. Increasing fertilizer application, particularly nitrogen, might promote infected plants to outgrow the infection. Using only PCV-free groundnut seed, or PMTV-free seed potatoes, and removing obviously infected potato plants can reduce the incidence of PMTV disease. Removing potential weed hosts, in which the fungal vectors might oversummer, and coating wheat seeds with fungicide before sowing are also beneficial. Because furoviruses can persist in resting spores for many years in soil, chemical sterilants (methylbromide or formaldehyde) and fungicides (captan and benomyl) can greatly diminish the incidence of SBWMV and PMTV in small plots, but are financially and ecologically impractical for large-scale field control.

In the long term, however, furoviruses are best controlled by the production and use of resistant cultivars. Studies on inheritance of field reaction to SBWMV indicate that: 1) resistance is controlled by a single locus; 2) resistance is dominant over susceptibility; 3 ) the resistance factor is shared between resistant cultivars originating from different sources; and 4) resistance may be directed to the wild-type SBWMV and not to spontaneous deletion mutants.

All presently available resistant cultivars are resistant to the virus but not to the fungal vector. In the USA, SBWMV-resistant cultivars (carrying the single dominant gene) are extensively infected when challenged with a combination of SBWMV and wheat spindle streak mosaic bymovirus (WSSMV). In France and Italy, some SBWMV-resistant wheat cultivars are still resistant to infection by the SBWMV-WSSMV complex, but the resistant American wheat cultivar Newton is susceptible to SBWMV in France. These results suggest that the pathogenesis of SBWMV from America or Europe is different and the mechanism of resistance to the virus needs to be studied. Different resistant germplasms should be selected and incorporated into breeding programmes.

Similarly, selection of potato or beet lines that are resistant or tolerant to potato mop-top or rhizomania has become a primary objective in breeding programmes in Europe, the USA and

Table II. Particle sizes and components of furoviruses (modified from Brunt, 1988).

\begin{tabular}{|c|c|c|c|c|c|c|c|c|c|}
\hline \multirow[t]{2}{*}{ Virus } & \multirow[t]{2}{*}{ Diameter $(\mathrm{nm})$} & \multicolumn{3}{|c|}{ Length (nm) } & \multirow[t]{2}{*}{ Coat protein (kDa) } & \multicolumn{4}{|c|}{$R N A \operatorname{sizes}(k b)$} \\
\hline & & Long & Intermediate & Short & & 1 & 2 & 3 & 4 \\
\hline BBNV & 25 & 250 & 150 & & - & - & - & & \\
\hline BNYVV a & 20 & 390 & 265 & $65-105$ & 21 & 6.7 & 4.6 & 1.8 & 1.5 \\
\hline BSBV & 19 & 300 & 150 & 65 & - & - & - & - & \\
\hline $\mathrm{HMV}$ & 22 & 240 & 120 & & - & - & - & & \\
\hline IPCV & 20 & 249 & 184 & $60-100^{b}$ & & 5.4 & 4 & & \\
\hline NVMV & 18 & 700 & $125-175$ & & 21.4 & 8.0 & 3.0 & & \\
\hline OGSV & 20 & 305 & 152 & & 19 & 6.2 & 3.5 & & \\
\hline $\mathrm{PCV}$ & 21 & 245 & 190 & & 23 & 5.9 & 4.3 & & \\
\hline PMTV & 17 & 290 & $100-150$ & & 24.3 & 6.4 & 3.0 & 2.5 & \\
\hline RSNV & 20 & 380 & 270 & $110-160$ & - & - & - & - & \\
\hline SBWMV & 20 & 300 & 150 & & 19.7 & $6.9-7.1$ & $3.5-3.6$ & & \\
\hline SCSV & 20 & 260 & 140 & & 20.5 & 6.2 & 3.5 & & \\
\hline
\end{tabular}

\footnotetext{
a A 1.4 kb RNA5 has been reported in some Japanese isolates (Richards and Tamada, 1992; Shirako and Wilson, 1993). b May be fragments of the long or intermediate particles. - No information.
} 
Japan. Many cultivars of potato are known to be resistant to PMTV, and can be used to minimize crop losses in sites where the virus is endemic. The use of virus-resistant cultivars is also likely to minimize losses attributable to BNYVV and other furoviruses.

\section{MORPHOLOGY AND COMPOSITION OF PARTICLES}

Furoviruses have rod-shaped particles about $20 \mathrm{~nm}$ in diameter but the length distributions of different viruses are not uniform (table II). BBNV, HMV, IPCV, OGSV, PCV, PMTV and SBWMV are usually of 2 modal lengths (150 and $300 \mathrm{~nm}$ ), while BNYVV, BSBV and RSNV are of 3 lengths $(390,270$ and $110 \mathrm{~nm})$. NVMV has been reported to have particles up to $700 \mathrm{~nm}$, but the range is usually 125 to $175 \mathrm{~nm}$. Spontaneous deletions are a common characteristic of the furoviruses, regardless of the strains and the modes of infection.

The coat protein of the viruses is composed of many copies of a single polypeptide with molec- ular weights variously reported as 19-24.3 kDa (table II). Optical diffraction of BNYVV particles has shown that the protein has helical symmetry; the single-start, right-handed helix has a $2.6 \mathrm{~nm}$ pitch with repeat turns involving 49 subunits of the $21 \mathrm{kDa}$ protein. Each single-stranded, plussense genomic RNA component is encapsidated separately in the coat protein and, in all cases, RNA comprises only about $5 \%$ of the particle weight.

\section{SEROLOGY AND EPITOPES}

Among the furoviruses, OGSV, SCSV, PMTV and BBNV are serologically related to SBWMV. No serological relationship is detected between PCV and IPCV although the coat protein of IPCV is $61 \%$ identical to that of PCV. BNYVV is not serologically related to any member of the group.

As mentioned previously, SBWMV and PMTV also have distant relationships with TMV. OGSV has distant serological relationships with bean yellow mosaic potyvirus (BYMV), strain relation-
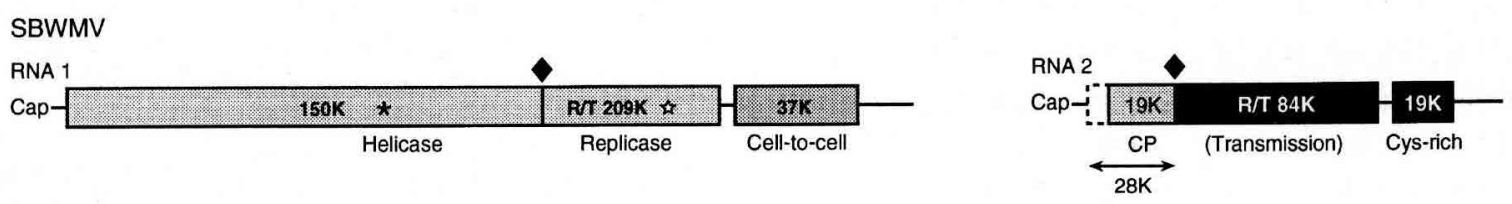

BNYVV
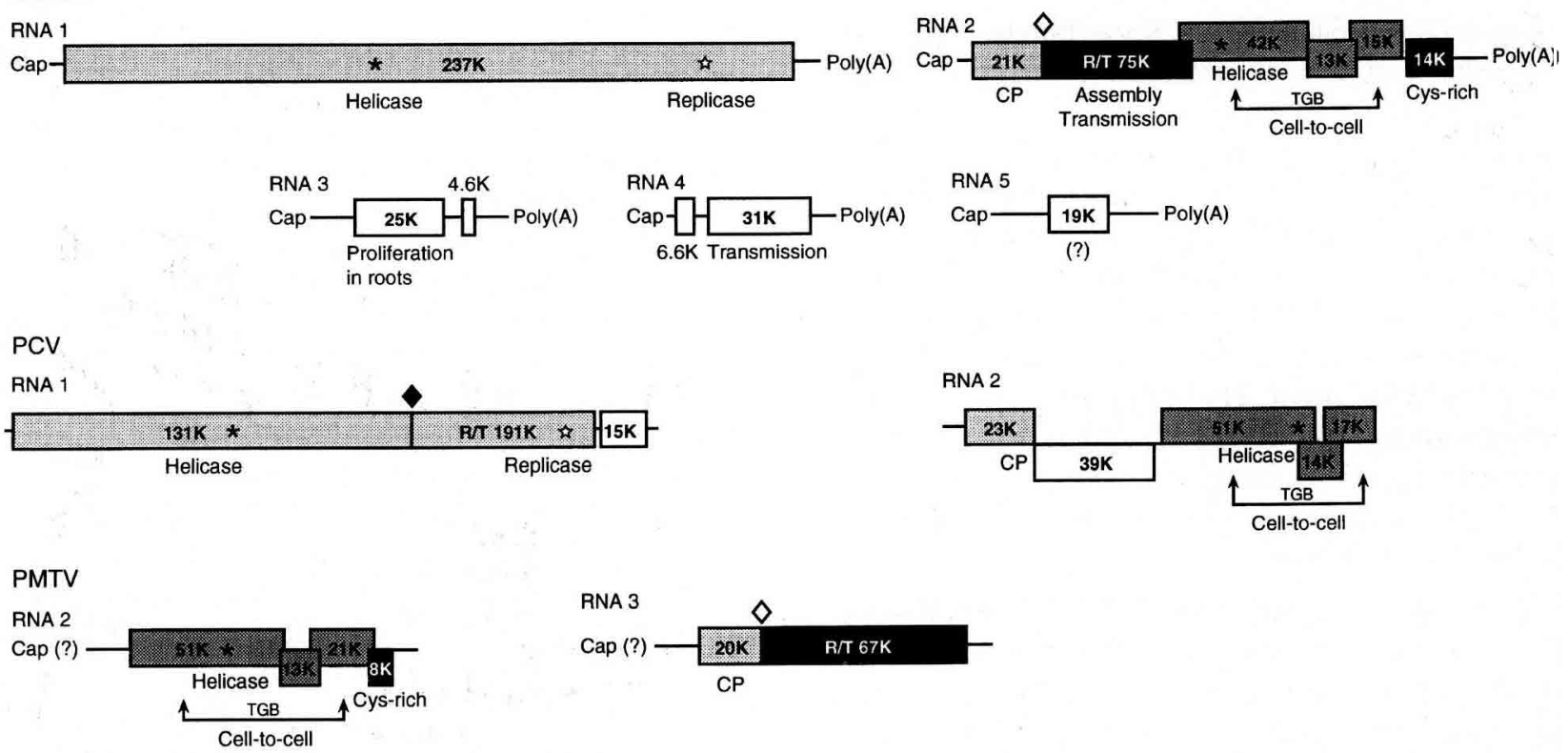

Fig 1. Genome organization of the better-known furoviruses. From the top, SBWMV (US Nebraskan wild-type isolate; modified from Shirako and Wilson, 1993), BNYVV (based on Jupin et al, 1991), PCV (based on Herzog et al (1994) and Manohar et al (1993)) and PMTV (isolate T, based on Scott et al (1994) and Kashiwazaki et al (1995); RNA1 sequence data not yet available). Sizes of polypeptide products are given as $\mathrm{K}(\mathrm{kDa})$ and their unknown (?), putative (?) or true function (s), based on amino acid sequence homologies or mutant analyses, are described below. Readthrough portions are shown as R/T and the total mol.wt as (K). The $3^{\prime}-$ tRNA-like terminus of SBWMV and PMTV RNA2 is presented by a cloverleaf, and the NTP-binding helicase and GDD replicase domains by asterisks and stars, respectively. Leaky amber or opal stop codons are indicated by open or filled diamonds, respectively. 
ships with bean yellow mosaic potyvirus (BYMV, strain $G$ ), potato virus and red clover vein mosaic carlaviruses (PVM and RCVMV) and perhaps HMV. BBNV is unrelated to TMV, but related to cucumber green mottle mosaic and odontoglossum ringspot tobamoviruses (CGMMV and ORSV).

Mouse monoclonal antibodies (MAbs) against SBWMV, BNYVV or PMTV have been produced and used for coat protein epitope mapping in virions. Five, 7 and 3 regions, which are involved in the formation of epitopes, have been demonstrated on the coat protein of BNYVV, PMTV and SBWMV, respectively.

\section{ORGANIZATION OF THE GENOME AND EXPRESSION OF THE BETTER KNOWN FUROVIRUSES}

Table II summarizes the genome composition of the confirmed and possible members of the Furovirus genus. Both RNA1 and RNA2 of SBWMV, PCV and BNYVV are essential for virus infectivity. PMTV may need RNA3 in addition to RNA1 and RNA2. Figure 1 shows a comparison of the genome organization of the better known furoviruses (SBWMV, BNYVV, PCV and PMTV).

Complete sequence analyses indicate that the proteins encoded by RNA1 of SBWMV, PCV and BNYVV have significant homology with the nonstructural proteins of other plant/animal RNA viruses of the Sindbis-like superfamily, implying that RNA1 codes for proteins involved in RNA replication (eg, with the 'GDD' consensus sequence for RNA replicase and the NTP-binding motif 'GXXGXGKX/T' for RNA helicase). SBWMV cell-to-cell transport is controlled by a $37 \mathrm{kDa}$ protein which is coded by a single gene located at the 3'-end of RNA1. In contrast, the cell-to-cell movement proteins of other furoviruses (BNYVV, PCV, PMTV and NVMV), are similar to potexviruses, carlaviruses and hordeiviruses, consisting of a 'triple gene block'. In BNYVV, PCV, PMTV and NVMV these genes are located at the 3 '-end of RNA2.

In vitro translation of SBWMV, PCV and BNYVV RNAs showed that all capsid proteins are encoded by the most 5'-proximal open reading frame on RNA2. Following the coat protein gene, all the furoviruses studied have a coat protein readthrough domain which might be associated with fungal transmission. At the $3^{\prime}$-end of RNA2 of SBWMV, BNYVV and PMTV is a gene for a 8-19 kDa polypeptide which is rich in cysteine and its function is unknown.
Taxonomically, therefore, furoviruses constitute a very diverse group of genome organizations and sequence homologies. The dominant characteristics of the taxon-fungus vector, rodshaped, can thus be seen as broad features of several genetic formats.

\section{REFERENCES}

Brown $F$ (1989) The classification and nomenclature of viruses. Summary of results of meeting of the International Commitee on Taxonomy of Viruses in Edmonton, Canada, August 1987. Intervirology 30 , 181-186

Brunt AA (1988) Labile rod-shaped viruses transmitted by plasmodiophorid fungi: furoviruses. In: Developments in Applied Biology II. Viruses with Fungal Vectors (Jl Cooper, MJC Asher, eds), Assoc Appl Biol, UK, 3-17

Campbell RN (1993) Persistance: a vector relationship not applicable to fungal vectors. Phytopathology 83 , 363-364

Chen J, Swaby AG, Adams MJ, Ruan Y (1991) Barley mild mosaic virus inside its fungal vector, Polymyxa graminis. Ann App/ Biol 118, 615-621

Herzog E, Guilley H, Manohar SK et al (1994) Complete nucleotide sequence of peanut clump virus RNA1 and relationships with other fungustransmitted rod-shaped viruses. J Gen Virol 75, 3147-3155

Jupin I, Tamada T, Richards KE (1991) Pathogenesis of beet necrotic yellow vein virus. Semin Virol 2, 121-129

Kashiwazaki S, Scott KP, Reavy B, Harrison BD (1995) Sequence analysis and gene content of potato mop-top virus 3: further evidence of heterogeneity in the genome organization of furoviruses. Virology 206, 701-706

Manohar SK, Guilley H, Dollet M, Richards K, Jonard $G$ (1993) Nucleotide sequence and genetic organization of peanut clump virus RNA2 and partial characterization of deleted forms. Virology 195, 3341

Richards KE, Tamada T (1992) Mapping functions on the multipartite genome of beet necrotic yellow vein virus. Annu Rev Phytopathol 30, 291-313

Rysanek P, Stocky G, Haeberle AM, Putz C (1992) Immunogold labelling of beet necrotic yellow vein virus particles inside its fungal vector, Polymyxa betae K. agronomie 12, 651-659

Scott KP, Kashiwazaki S, Reavy B, Harrison BD (1994) The nucleotide sequence of potato mop-top virus RNA2: a novel type of genome organization for a furovirus. J Gen Virol 75, 3561-3568

Shirako Y, Wilson TMA (1993) Complete nucleotide sequence and organization of the bipartite RNA genome of soil-borne wheat mosaic virus. Virology $19,516-532$ 